\title{
Laziness or liberation? Labor market policies and workers' attitudes toward employment flexibility
}

Lena Hipp ${ }^{1}$, Christopher J. Anderson ${ }^{2}$

${ }^{1}$ WZB Social Science Center Berlin, Berlin (Germany)

${ }^{2}$ Cornell University, Ithaca, New York (USA)

Running head: Attitudinal employment flexibility

Key words: labor market flexibility, policy feedback, attitudes, flexicurity, multi-Level analysis, international comparison

Correspondence to

Lena Hipp

WZB Social Science Center Berlin

Reichpietschufer 50

D-10785 Berlin

Tel: + 4930 25491- 232

E-mail: lena.hipp@wzb.eu 


\begin{abstract}
This study examined the relationship between labor market policies and employees' willingness to make concessions in order to avoid unemployment. In contrast to previous work that analyzed actual behavior of employers and the unemployed, we examined how labor market policies influence employees' flexibility. We therefore applied multi-level modeling techniques to a dataset that we created by combining individual-level data from the International Social Survey Program (ISSP) with country level-information from the Organization for Cooperation and Economic Development (OECD). The main findings of our analyses are that dismissal protection and unemployment benefits do make a difference to employees' willingness to make concessions and that the relationships between the willingness to make concessions and labor market policies are non-linear. Substantively, these non-linear relationships suggest that employees' willingness to be flexible is negatively associated with both "too much" and "too little" social protection.
\end{abstract}

Since the mid-1980s, policy makers in the industrialized world have increasingly sought to combat mass unemployment by cutting back on social provisions and deregulating labor markets. They have loosened the restrictions on firing permanent workers, reduced restrictions on hiring temporary workers, cut unemployment and welfare benefits, and established work-first programs (e.g., Fleckenstein, 2008; Fleckenstein, Saunders, \& SeeleibKaiser, 2011; Kalil, Seefeldt, \& Wang, 2002; Zylan \& Soule, 2000). A sizable literature in economics and sociology has investigated the effects of these policies on the functioning of the labor market, particularly on unemployment duration and labor market transitions (e.g., Esping-Andersen \& Regini, 2000; Kahn, 2007; Lazear, 1990; Siebert, 1997; Western \& Beckett, 1999). While the general focus of these studies has been on the unemployed, that is, 
those outside of the labor market, virtually no attention has been paid to the effects of labor market policies on employees, that is, on individuals inside the labor market.

Whether and how labor market policies impact employees, therefore, is an open and crucially important question. In the industrialized world, the size of the employed population is disproportionately higher than the size of the unemployed population. These individuals participate in elections, reward politicians for policies they like, and sanction them for policies they dislike. They contribute to the welfare of businesses and organizations and to societal well-being by going to work every day and by quickly seeking new work in the case of unemployment. Employees' attitudes toward work, in particular their willingness to be flexible in order to keep their jobs and find new ones, also have important consequences for the well-being of individuals, organizations, and the economy in general. They affect individuals' health and ability to manage family obligations, organizational commitment, and reservation wages. In short, researchers and policymakers should care about the effects of labor market policies on employees' attitudes, since they potentially affect economic output as well as the demand for and acceptance of policy changes.

In this study, we therefore examined workers' attitudes towards flexibility, in particular the association of these attitudes with labor market policies such as dismissal protection and unemployment benefits, as these policies have been shown to affect the behaviors of employers and the unemployed (e.g., Abraham \& Houseman, 1994; Addison \& Teixeira, 2003; Addison, Teixeira, \& Grosso, 2000; Anderson, 2009; Gebel \& Giesecke, 2009; Kahn, 2007; Lalive, 2007; van Ours \& Vodopivec, 2006). Do stringent levels of dismissal protection and generous unemployment benefits reduce workers' willingness to be flexible, or do they make them more inclined to sacrifice portions of their income or accept longer working hours in order to keep a job or find a new one? Generally speaking, is there 
evidence that policies shape how employees view the incentives to remain employed or to retain certain employment conditions?

To answer these questions, we drew on the literature on policy feedback (e.g., Bruch, Ferree, \& Soss, 2010; Campbell, 2003; Kumlin, 2004; Kumlin \& Rothstein, 2005; Mettler \& Soss, 2004 for review; Soss, 1999) and on the effects of dismissal protection and unemployment benefits on employment performance (e.g., Bertola, 1999; Bertola, Blau, \& Kahn, 2007; Blanchard \& Landier, 2002; Cahuc \& Postel-Vinay, 2002; Kugler \& Pica, 2008). Our argument is that labor market policies not only have an impact on the behavior of the unemployed and employers (as previous studies have shown), but also on employees' attitudes toward employment flexibility, that is, their willingness to accept inconveniences in order to avoid unemployment. Moreover, we suggest that the direction of the association depends on the extent and the design of these policies.

We use the term "attitudinal employment flexibility" to describe employees' willingness to make concessions in order to avoid unemployment, and define it as the willingness of individuals to adapt to changing organizational or labor market requirements. Attitudinal flexibility includes the willingness to be retrained, travel long distances to work, work on temporary contracts, or accept income losses. We use the term attitudinal employment flexibility to delineate this psychological, individual-level concept from the more commonly used and related term "labor market flexibility," which denotes the efficiency of labor markets in coordinating the supply of and demand for workers. Whether attitudinal employment flexibility is desirable or undesirable depends on the actor's perspective. While firms and the economy at large may benefit from a flexible workforce, accepting a job with lower pay, participating in training, or commuting a longer distance to work may be unpleasant and costly for individuals. 
The article is organized as follows. First, we introduce the notion of policy feedback. We then review the existing literature on the effects of labor market policies on employment outcomes in order to understand how these policies may affect employees' willingness to be flexible to avoid unemployment. Based on this review, we suggest a non-linear relationship between workers' attitudinal employment flexibility and both dismissal protection and unemployment benefits. We tested these hypotheses by analyzing a dataset that we created by combining individual-level data from the 2005 wave of the International Social Survey Program (ISSP) with national-level information on welfare states from the Organization of Economic Cooperation and Development (OECD). The results of our multi-level analyses are discussed in the next section of the article. The concluding section presents the limitations of the study and indicates directions for further research.

\section{Public policies and attitudinal employment flexibility: a case for policy}

\section{feedback}

To understand how labor market policies matter for the employed, we position our study in a growing stream of scholarship in political science and sociology that has investigated why and how government programs and public policies affect individual attitudes and behavior, which in turn generate demands for new policies (e.g., Anderson, 2009; Bruch et al., 2010; Campbell, 2003; Kumlin \& Rothstein, 2005; Mettler, 2002; Mettler \& Soss, 2004; Soss, 1999). The general notion underlying the studies on policy feedback is that citizens (and in our case, workers) are nested within particular policy regimes, and that how policies are designed shapes people's attitudes and behaviors (e.g., Campbell, 2008; Givan \& Hipp, 2012).

Public policies convey meaning and information to citizens, they shape preferences and beliefs, and hence they - intentionally or unintentionally - affect even those who are not 
the immediate targets of a particular policy (Hacker, 2002; Pierson, 1993; Skocpol, 1992). For example, there is evidence that people's sense of job security as well as facets of their private lives, such as their social ties, are significantly shaped by labor market policies (e.g., Anderson, 2009; Anderson \& Pontusson, 2007; Chung \& van Oorschot, 2011; Dixon, Fullerton, \& Robertson, 2013). Policy feedback effects lead us to look for effects of policies on populations that are consistent with the logic of their design - that is, it is a simple rational choice approach suggesting that policies affect individuals' incentives to believe and do certain things.

For the purposes of our analysis, we focused on dismissal protection and unemployment benefits as the most immediate and proximate macro-political factors that affect work-related attitudes. Given that all employees are theoretically at risk of being laid off at some point during their careers - although the likelihood and the duration differs considerably across individuals and countries - we suspected that these policies also affect the perceived necessity to be flexible in order to keep a job or quickly find a new one. Because the design and the extent of labor market policies vary considerably across countries, we used cross-national comparisons that allowed us to examine the relationship between attitudinal employment flexibility and both dismissal protection and unemployment benefits.

\section{The design and variation of labor market policies in cross-national perspective}

Dismissal protection can best be thought of as a form of tax paid by the employer in case of layoffs (OECD 2004, p. 65). By increasing the costs of firing workers, dismissal protection makes firing more difficult and therefore less likely. Unemployment benefits include both the compensation employees receive upon losing their jobs and the assistance they receive in finding a new job (i.e., counseling, training, or wage subsidies). It is important that both types 
of labor market policies be present in order to strengthen the individual worker's position visà-vis the employer: stringent dismissal protection makes it more difficult for the employer to lay off an employee and generous unemployment benefits provide employees with an alternative source of income.

Figure 1 displays the variation in the strength of dismissal protection and the generosity of unemployment benefits in our sample countries. In the U.S., for example, it is easy for employers to lay off workers and workers also do not have much to expect financially from their government in case of unemployment. The reverse is the case for Germany, France, or Spain. Denmark, whose policies best exemplify the EU's idea of flexicurity ${ }^{1}$, combines low levels of dismissal protection with generous levels of unemployment benefits.

\section{Insert Figure 1 about here}

Although neo-classical economics posits that low levels of dismissal protection should increase the creation of new jobs, empirical research has found that they do not necessarily lead to lower unemployment rates, since the lowered cost of offering jobs may be offset by higher exit rates from employment (e.g., Bertola et al., 2007; Blanchard \& Landier, 2002; Cahuc \& Postel-Vinay, 2002). The stringency of dismissal protection is thus not correlated with overall unemployment rates (Nickell, 1997; Nickell \& Layard, 1999), but it does have a positive association with employment rates, partly because of a higher level of temporary employment (Boeri \& Garibaldi, 2007; Booth, Francesconi, \& Frank, 2002; Kahn, 2007, 2010; Kugler, Jimeno, \& Hernanz, 2005).

\footnotetext{
${ }^{1}$ With its idea of "flexicurity", the European Commission sought to combine flexible labor markets with income and employment security for workers (European Commission, 2007; Muffels, 2008; Ton Wilthagen, 1998; T. Wilthagen \& Tros, 2004). "Flexicurity" is presented as a sort of "magic word," intended to satisfy both organizations with their needs for flexibility and employees with their needs for security. Dismissal protection and unemployment benefits are the main knobs which can be adjusted to ensure this flexibilitysecurity nexus (Wilthagen \& Tros, 2004).
} 
Likewise, the relationship between unemployment benefits and employment is also ambiguous. By providing temporary income support to those who have lost their job involuntarily, unemployment benefits can act as a disincentive to finding new employment, and as an economic stabilizer that helps individuals find jobs that match their qualifications and needs (e.g., Gangl, 2003; Young, 2010). One consistent finding in the literature on the effects of unemployment benefits is that the average duration of unemployment increases the longer benefits are paid, and that the likelihood of finding a new job increases considerably just before the benefits run out (e.g., Card \& Levine, 2000; Chetty, 2008; Young, 2010). Some scholars interpreted this finding as a labor-leisure tradeoff, i.e., individuals prefer not to work if they do not have to, while others consider longer search periods to be positive as they contribute to better job matching (Decker, 1997; Fredriksson \& Holmlund, 2006; Gangl, 2003). ${ }^{2}$

However, whether and how labor market policies impact individuals' attitudes towards work, especially the attitudes of those currently in the labor force, remains an open question. Are employees less willing to accept a decrease in pay or a longer commute when they know that they are well-protected against layoffs and/or when they know they will not need to accept an inferior or poorly matched job to sustain their living in case of layoff? Despite the known importance of attitudinal employment flexibility for individual, organizational, and macro-economic outcomes, it remains unclear whether welfare state and labor market policies impact what people think they need to do to ensure continued employment.

\section{Relationship between labor market policies and attitudinal employment \\ flexibility}

\footnotetext{
${ }^{2}$ For the case of the U.S., an increase in re-employment at the time when benefits are about to expire may also be due to the fact that employers recall many laid-off employees. That is, they use unemployment to achieve temporary layoffs.
} 
Based on these theoretical considerations and the empirical findings on the relationship between labor market policies and labor market outcomes, two opposing predictions about the impact of labor market policies on workers' attitudes are possible. Viewed instrumentally, greater empowerment through stringent dismissal protection and generous unemployment benefits should make employees less willing to be flexible, that is, it should reduce workers' attitudinal employment flexibility. Employees may be confident of keeping their jobs because they have high levels of dismissal protection or because they know that, in case of layoff, they will be able to sustain their material well-being thanks to generous unemployment benefits.

Since extensive employment protection and unemployment benefits enhance "matching processes" in the labor market, individuals in such a context are more likely to work in jobs that optimally match their skills and qualifications. Stringent dismissal protection requires employers to select their employees more carefully, lest they get stuck with an unproductive workforce they cannot make redundant; unemployment benefits help workers find jobs that match their skills rather than having to take any job that comes along (Acemoglu \& Shimer, 2000; Chetty, 2008; Gangl, 2003, 2006; Pissarides, 2000). Having a "good" job, in turn, can generate feelings of entitlement and may therefore make the individual employee less willing to accept a job of inferior quality. Thus, when jobs and income (current or future) are secure, we should see less attitudinal employment flexibility.

The competing perspective is that job and income security increase workers' attitudinal employment flexibility. Research has shown that individual well-being decreases sharply in the event of unemployment and that individuals fear becoming unemployed (Clark \& Postel-Vinay, 2009; Jahoda, 1982). The logic is that unemployment is not a prolonged holiday but rather a state that individuals seek to avoid and exit quickly. If individuals know that the odds of quickly finding a new job of comparable quality are high - for example because they were unemployed themselves and did not have trouble getting re-employed, or 
because they have seen friends, relatives, or colleagues navigate the job market without problems - they may be less scared of unemployment. Individuals living in countries with high levels of unemployment benefits, however, are less likely to have experienced frequent layoffs. Therefore, they may actually be even more worried about unemployment and, hence, more willing to be flexible in order to avoid unemployment than their counterparts in countries with low levels of dismissal protection. ${ }^{3}$

Likewise, the prospect of receiving generous unemployment benefits in case of layoff may also have positive effects on potential recipients. In many countries, receiving unemployment benefits is associated with the need to actively search for work. As a result, employees may anticipate the demands of active labor market and work-first programs that are attached to the receipt of benefits (e.g., Anderson, 2009; Fleckenstein, 2008; Zylan \& Soule, 2000). In addition, social norms and customs may also play a role (e.g., Biggart \& Castanias, 2001; Elster, 1986; Frank, 1993; Pescosolido, 1992; Simon, 1957; Smith, 1991; Tversky \& Kahneman, 1981). Receiving benefits can induce a sense of gratitude or sense of obligation, which, in turn, is reciprocated by the effort to do whatever is necessary to find new work (Akerlof, 1982; Young, 2010). Since such feelings of forced or voluntary reciprocity may also be anticipated, generous unemployment benefits may actually be associated with greater attitudinal employment flexibility.

In sum, if we assume that individuals take existing policies and regulations into account when thinking about their future employment situation, as the research on policy feedback does, two opposing - though equally convincing - hypotheses regarding employees' employment flexibility are plausible. Since individual behaviors can be guided by rational self-interest, that is, the desire to maximize outcomes, as well as by social needs and expectations, that is, the desire to ensure a basic level of security and to conform to informal

\footnotetext{
${ }^{3}$ These worries are justified given that dismissal protection and unemployment duration have been found to be positively associated (e.g., Addison \& Teixeira, 2003; Addison et al., 2000).
} 
norms and customs of gratitude and reciprocity, both of the forces outlined above may be at work simultaneously. We therefore combined elements of both interpretations. Specifically, we posited that low to moderate levels of protection and benefits will be positively associated with workers' attitudinal employment flexibility, since they ensure some basic level of security that individuals need to be able to intrinsically value work. Such low to moderate levels of protection, moreover, are likely to enjoy broad societal support because they are available to everyone and not only particular groups of workers (Rueda, 2005). At the same time, we assumed protection and benefits beyond a certain threshold induce feelings of entitlement and therefore reduce attitudinal employment flexibility. In other words, we expected that up to a certain level, dismissal protection will be associated with increasing attitudinal employment flexibility but that this positive association will level out or even decline above a certain threshold. Likewise, the prospect of only getting a basic level of material security will make workers more willing to be flexible when it comes to keeping their current job or finding a new one but, again, if these benefits are paid beyond a certain limit, the effect will also level off or even decline.

\section{Methodology}

\section{Data}

We tested these hypotheses by applying multi-level modeling techniques to a dataset that combined individual-level data from the International Social Survey Program (ISSP) with country-level information from the Organization of Economic Cooperation and Development (OECD). ${ }^{4}$ The ISSP is an ongoing, collaborative survey of a wide array of countries with annually changing survey topics. For our analyses, we used the 2005 survey on work

\footnotetext{
${ }^{4}$ More information about the ISSP data can be found at www.issp.org and more information about the OECD data at http://www.oecd-ilibrary.org/statistics.
} 
orientations. The OECD collects country-level information on important economic indicators, such as unemployment rates, social expenditures, and employment regulation, on a regular basis and standardizes the data to allow for international comparisons.

To assess workers' attitudinal employment flexibility, we created an additive measure consisting of four questions that asked respondents what they would be willing to do to avoid unemployment. This included accepting a position with lower pay, accepting temporary employment, accepting a longer commute to work, and learning new skills. Answers ranged from "strongly agree" to "strongly disagree". Higher values indicate greater attitudinal employment flexibility. A Cronbach's alpha of 0.73 suggests that our measure has high internal consistency. Figure 2 displays the weighted overall mean of employees' attitudinal employment flexibility in our study countries, broken down into the four single components.

\section{Insert Figure 2 about here}

With means of 11.6 and 12.0, Japan and Hungary are the countries with the lowest average levels of attitudinal flexibility, while Switzerland and Germany are the highest with 15.3 and 15.0, respectively. When the countries are grouped into regional clusters, that is, Asia, Anglo-Saxon countries, Continental Europe, Eastern Europe, Southern Europe, and Scandinavia, the figure also shows that, with the exception of the Scandinavian countries, the

within-cluster variance in attitudinal employment flexibility is as large as the between-country variance.

The main independent variables in this study were dismissal protection and unemployment benefits. The strength of dismissal protection was measured using an indicator capturing the protection of individual workers against dismissal, special requirements for collective dismissals, and the regulation of temporary forms of employment (OECD, 2004, p. 65). The generosity of unemployment benefits was measured by taking national expenditures on the material assistance workers received in case of layoff and expenditure on services 
helping workers to find new jobs by providing training, consulting, and subsidizing the creation of new jobs. This measure is provided in percentage GDP and adjusted based on the number of unemployed individuals.

To account for alternative reasons that may make workers more willing to be flexible in order to remain gainfully employed, we included the following control variables in our analyses. At the individual level we included gender $(1=$ female $)$, age (in years) and its square term, education in years (centered by country), relationship status ( $1=$ being single), partner's flexibility $(1=$ inflexible partner due to disability or full-time work $)$, children $(1=$ having a child/several children living in one's household), working full time ( $1=$ full time), union membership $(1=$ being a union member $)$, position at work $(1=$ working in a supervisory position), type of work $(1=$ being a blue collar worker), and job satisfaction $(1=$ not satisfied at all to $7=$ very satisfied). These variables have been shown to affect individuals' attitudes regarding labor market flexibility (e.g., Bernhardt \& Krause, 2014; Soidre, 2004). On the country level, we sought to control for labor market trends using standardized unemployment rates averaged over the last 5 years and a dummy variable (1 indicating that unemployment between 2004 and 2005 goes down). By restricting the analysis to employees working at least part-time and to those countries for which macro-level indicators were available, the final sample yielded a total of 13,358 observations in 20 countries. The means, standard deviations, and correlations among our study variables are displayed in Table 1.

\section{Insert Table 1 about here}

\section{Analyses}

Because we examined differences across countries and combined individual with nationallevel data in our analyses, we estimated multilevel models. Ignoring the nested structure of the data would likely lead to underestimated standard errors and erroneous conclusions about 
the statistical significance of relationships between the study variables (e.g., Rabe-Hesketh \& Skrondal, 2012). Our linear random intercept model took the following form:

$$
Y_{i j}=\beta_{0}+\sum \beta_{k} X k_{i j}+\sum \beta_{p} Z_{p j}+u_{0 j}+e_{i j}
$$

, where

$$
\begin{array}{ll}
\mathrm{Y}_{\mathrm{ij}} & \text { is the variable representing the employment flexibility of individual } i \\
\beta_{0} & \text { in country } j \\
\beta_{\mathrm{k}} & \text { is the overall intercept } \\
\mathrm{X}_{k i j} & \text { is the individual-level characteristic } k \text { for individual } i \text { in country } j \\
\beta_{\mathrm{p}} & \text { is the fixed country-level parameter } p \\
\mathrm{Z}_{p j} & \text { is the country-level characteristic } p \text { for country } j \\
\mathrm{u}_{0 \mathrm{j}} & \text { is the country-specific deviation from the overall intercept } \\
\varepsilon_{\mathrm{ij}} & \text { is the residual for individual } i \text { in country } j .
\end{array}
$$

This model assumes that the error components on both the individual level and the country level are normally distributed and have equal variance and a mean of zero, that is, $\mathrm{u}_{\mathrm{j}} \sim$ $\mathrm{N}(0, \psi)$ and $\varepsilon_{\mathrm{ij}} \sim \mathrm{N}(0, \theta)$. We used Stata's xtreg command to estimate our models and ran tests of normality and heteroscedasticity, that is, for level 2 we examined the variance inflation factors (VIFs) of an OLS regression on country-level averages with macro-level variables as the only predictors - but they did not indicate violations of these assumptions.

To assess the model fit, we calculated the amount of the explained variance separately for every level, that is, we determined the R-square as the proportional reduction of residual variance in comparison with the empty model, that is,

$$
R_{I N D I V}^{2}=\frac{\sigma_{\varepsilon}^{2}(\text { empty })-\sigma_{\varepsilon}^{2}}{\sigma_{\varepsilon}^{2}(\text { empty })}
$$

and

$$
R_{\text {CONTEXT }}^{2}=\frac{\sigma_{u_{0}}^{2}(\text { empty })-\sigma_{u_{0}}^{2}}{\sigma_{u_{0}}^{2}(\text { empty })},
$$

and compared the deviances (i.e., -2LogLikelihood) of the various models. We calculated the chi-square value by subtracting the deviance of the restricted model from the deviance of the 
extended model. Statistically significant chi-square results of the model comparisons indicated a better fit.

\section{Results}

The results of our analyses are presented in Table 2. First, we ran an "empty" model (Model 1), which did not include any of our independent variables and therefore only estimated the intercept. Based on this empty model, we calculated the intra-class correlation $\rho$ (ICC), which indicated how much of the variance in the dependent variable is due to differences among individuals versus differences among countries. The intra-class correlation coefficient of Model 1 was of 0.07 , which means that around 7 percent of the variance in employment flexibility could be explained by differences among countries. This suggests that where a person lives in the world does indeed matter for attitudinal employment flexibility.

Table 2 about here

When the individual level variables were included (Model 2), the ICC stayed approximately the same, suggesting that only a very small proportion of individuals' willingness to be flexible across countries is due to compositional effects, that is, systematic differences among individuals across countries. Overall, the coefficients of the individual level variables were straightforward and confirmed what one would generally expect regarding their relationship with attitudinal employment flexibility.

As the coefficients of the terms for gender and number of children were not statistically significant, we also included an interaction term between gender and number of children. The reasoning is that women with children may be less willing - or, probably, less able - to be flexible than men with children. The statistically significant interaction term between gender and presence of children in the household confirmed this expectation. Thus, attitudes towards flexibility indeed differ between men and women with children. The effect 
of age is non-linear (statistically significant coefficients for both age and its squared term), suggesting that employment flexibility increases with age but flattens outs over time. Union membership, public sector employment, and the flexibility of the spouse or partner did not seem to affect attitudinal employment flexibility - at least not in a way that was similar across all countries ${ }^{5}$.

Education, the type of work, working full time, having a supervisory position at work, and job satisfaction, however, all had a statistically significant relationship with attitudinal employment flexibility. We believe that these results were driven by both needs and opportunities. Although highly educated workers usually have better employment opportunities than low-skilled workers, there are also fewer job opportunities that match their more specific skills and qualifications. The same applies to jobs involving supervisory responsibilities. Therefore, it is not surprising that the coefficients for education and supervisory position were both positive and statistically significant. Furthermore, these individuals were probably accustomed to acquiring new skills and traveling longer to work, both of which serve to increase attitudinal employment flexibility. Workers in manual jobs tend to be less accustomed to being flexible than professionals and services workers, which should explain the negative coefficient for "blue collar worker". Full-time workers may be economically more dependent on their salary than part-time workers and therefore exhibit greater attitudinal employment flexibility. Those with high job satisfaction may value work more in general than those who are dissatisfied with their jobs, which may explain the positive and statistically significant coefficient of job satisfaction (e.g., Judge, Heller, \& Mount, 2002 on the relationship between personality and job satisfaction).

When the country-level variables were included (Model $3 \& 4$ ) - labor market conditions, unemployment benefits, and dismissal protection - none of the individual level

\footnotetext{
${ }^{5}$ It may be that the non-significance of these coefficients is due to the fact that union membership and public employment mean very different things in different countries.
} 
variables changed its sign or level of statistical significance. The coefficients for both variables on labor market conditions, that is, unemployment rates (averaged over the last five years) and recent changes in unemployment, failed to reach statistical significance at conventional levels. This may be because unemployment (both averaged rates and recent changes) varies considerably within countries and across industries and, therefore, our measures might simply have been too coarse to detect a statistically discernible effect on individuals' attitudes. Second, although unemployment rates change - both seasonally and over the course of different years - changes in structural unemployment turned out to be minor in the absence of major economic changes or reforms (Blanchard \& Katz, 1997; Blanchard \& Wolfers, 2000). Therefore, individuals might adapt to certain labor market conditions - either good or bad - and therefore remain unaffected in their attitudes towards labor market flexibility.

Finally, the coefficients for dismissal protection, unemployment benefits, and their respective square terms provided clear evidence supporting our thesis that labor market policies matter for employment flexibility, and that the relationship between labor market policies and employees' attitudes toward labor market flexibility is non-linear. Specifically, in Model 3, the coefficient for dismissal protection was negative, which suggests that higher levels of dismissal protection are associated with less employment flexibility. However, the coefficient was not statistically significant at $\mathrm{p}<0.05$. The coefficient for unemployment benefits, in contrast, was statistically significant and positive, which suggests that more generous unemployment benefits increase workers' willingness to be flexible.

By adding the square terms of both variables (Model 4), we increased the model fit (result of chi-square test of deviances is 7.87 and statistically significant with $p<0.05$ ) and gained a fuller picture of the patterns in the data. The signs of the coefficients for unemployment benefits (positive) and dismissal protection (negative) remained similar to 
those in Model 3, but both achieved conventional levels of statistical significance. The signs of the square terms went in the opposite direction to those of the simple terms, indicating that workers' employment flexibility increases with the generosity of unemployment benefits but that this effect levels out, which is displayed graphically in Figure 3. This is exactly the relationship we expected.

\section{Figure 3 about here}

In contrast, the relationship between dismissal protection and employment flexibility was exactly the opposite of our hypothesized inverse U-shape relationship. Workers' employment flexibility decreased with increasing levels of dismissal protection (as neoclassical economic theory would predict), and only beyond a certain level did dismissal protection have a positive effect. This "turning point" occured at a level of approximately 2.7 when we used the OECD-provided measure - the equivalent of the strength of dismissal protection in Norway. The estimated relationship between strength of dismissal protection and attitudinal employment flexibility is displayed in Figure 4.

\section{Figure 4 about here}

To assess the practical importance of labor market policies for individuals' attitudinal employment flexibility, we standardized the coefficients of the country-level parameters (results not shown). Based on these results, we could conclude that labor market policies, with a standardized coefficient of dismissal protection of -.092 and a standardized coefficient for unemployment benefits of .100, are much more important for workers' flexibility - their willingness to learn new skills, accept pay-cuts, work in a temporary position, or face longer commutes to work - than labor market conditions (standardized coefficient of average unemployment between 2000-05 .019; std. coefficient for recent changes in unemployment rates $\sim-.057)$. 


\section{Robustness checks}

To check the robustness of our results, we conducted several additional analyses. First, we examined the associations between the two types of labor market policies and the four single items of our composite measure separately. Overall, the bilateral relationships between both dismissal protection and unemployment benefits and individuals' willingness to learn new skills, to accept lower pay, to work in a temporary job, and to travel longer to work confirmed the findings based on the composite measure. To ensure that the results were not driven by those countries with a larger number of observations (the ISSP data were unbalanced, that is, the number of observations varied among countries between 431 and 1,076), we also compared the results presented above (based on the maximum likelihood estimator) to the results of an analysis using the restricted maximum likelihood estimator (REML). The results of the two estimation methods did not differ substantially, that is, we observed slight differences in the magnitudes of some of the coefficients and levels of significance but no changes in the signs of the coefficients nor in the overall presence or absence of statistical significance (results available upon request).

To ensure that our models did not suffer from omitted variable bias, we also ran an additional model, which included information about individuals' personality traits (several measures capturing the "Big Five"), their financial situation, and political orientations. Although including these variables improved the model fit on level 1, we could not include them in the main model as they were not available for Australia, Great Britain, Hungary, Norway, Sweden, Canada, Spain, Portugal, or Finland, and thus reduced the number of observations on level 2 by half.

To test for multicollinearity, we estimated an OLS regression on country-level averages with only macro-level variables as predictors; we did not find any indication of a 
problem when examining the variance inflation factors associated with these models (no values higher than 1.99).

\section{Discussion}

We suggest two explanations for why the relationship between unemployment benefits and attitudinal employment flexibility took the form of an inverse U-shape. The first suggests - in line with the arguments underlying the flexicurity debate (European Commission, 2007; Muffels, 2008; Ton Wilthagen, 1998; T. Wilthagen \& Tros, 2004) - that a certain basic level of material security may be associated with a greater willingness to be flexible, because workers may perceive unemployment benefits as "gifts" that need to be reciprocated (e.g., Akerlof, 1982; Young, 2010), or because they anticipate being required to participate in active labor market policies that imply flexibility (e.g., Hasenfeld, Ghose, \& Larson, 2004; Soss, Fording, \& Schram, 2008). However, a second, neo-classical view of labor market policies may also provide some insight into this phenomenon. Labor economists have suggested that individuals receiving generous unemployment benefits are inclined to prefer leisure to labor (e.g., Siebert, 1997). Employed workers know that they can afford to survive without an income for a longer period of time, and they may also feel entitled to use available benefits especially when their taxes and contributions to unemployment insurance are high. This may explain why the positive association between unemployment benefits and attitudinal employment flexibility leveled out at the high end.

Next, we turn to the U-shaped relationship between dismissal protection and workers' willingness to be flexible to avoid unemployment. Here, too, we can draw on the two competing perspectives on the relationship between dismissal protection and attitudinal flexibility and suggest that each provides part of the explanation. In countries with low levels of dismissal protection, such as the U.S., workers are accustomed to being flexible and are 
therefore willing to learn new skills and travel longer distances to work in order to avoid unemployment. With increasing levels of dismissal protection, however, attitudinal employment flexibility decreases. One explanation may be that employers are more likely to carefully select their personnel to ensure that the employee's qualifications and skills match the job requirements when the costs of firing are high. Furthermore, when an individual is employed in a job that matches his/her needs and skills, the prospect of forgoing income, working on a temporary contract, or being retrained may not be attractive. Finally, the reason why this initially negative association levels out and even becomes positive with higher levels of protection may be that employees in countries with stringent dismissal protection fear unemployment - either because they have not experienced it before or because they know that individuals in these countries often remain unemployed for long periods of time (Addison \& Grosso, 1996; Addison \& Teixeira, 2003; Addison et al., 2000; Siebert, 1997). ${ }^{6}$

In summary, our analyses showed that labor market policies, which are created to ensure efficient labor markets and social equity, also affect what people think about their work. The associations between attitudinal employment flexibility and two types of labor market policy, that is, dismissal protection and unemployment benefits, however, are non-linear. Although they share this non-linearity, there are also important differences between the two types of policies. While the positive effects of generous unemployment benefits level out, confirming our hypothesis of a "happy medium", the opposite is the case for dismissal protection. Increasing strength of dismissal protection is associated with lower levels of employment

\footnotetext{
${ }^{6}$ A closely related interpretation of the positive coefficient of the square term is that it is not stringent levels of dismissal protection per se that drive these results but rather the high proportion of temporary workers in those countries with high levels of dismissal protection. These employees essentially have no job security and therefore need to be flexible with respect to pay, type of work, and commuting time. Because of a lack of information in the ISSP data on what types of contract employees have, we are unfortunately unable to assess which of the two explanations is more plausible.
} 
flexibility, and it is only associated with an increase in employees' attitudes towards flexibility beyond a certain threshold.

\section{Conclusions}

In this study, we examined the relationship between labor market policies and workers' attitudes towards flexibility. Our study differed from previous work in that we focused on the effects of labor market policies on the employed rather than the unemployed. While the effects of these policies on labor market dynamics have received considerable attention in economics and sociology, the question of how these policies affect the attitudes of the employed - typically a much larger portion of the working-age population - is underresearched. This study sought to close this gap. Our starting point was the demand for labor market flexibility which has prevailed in most industrialized countries since the mid-1980s. By facilitating the hiring and dismissal of workers and increasing employees' incentives to quickly transition to a new job after a layoff, policymakers have sought to reduce structural and long-term unemployment. By lowering social benefits and protections, they have sought to increase incentives to work. Both of these strategies are predicted to reduce unemployment according to a neo-classic analysis of labor market supply.

By linking macro-level welfare state policies with individual-level attitudes and perceptions, we expanded on existing research in economics and sociology on labor market flexibility and its consequences (Giesecke, 2009; Giesecke \& Gross, 2003). We showed that both dismissal protection and unemployment benefits are associated with attitudinal employment flexibility. The generosity of unemployment benefits was found to be positively associated with workers' willingness to be flexible in order to avoid unemployment - but only up to a certain level. The reverse is the case for dismissal protection: dismissal protection 
only has a positive association with employment flexibility at the low end of the spectrum and beyond a certain threshold.

While we attribute these findings to differences in feelings of reciprocity and entitlement, as well as to workers' experiences with unemployment and the need to be flexible, our data could help us identify these causal pathways with certainty because the data we used in our analyses were cross-sectional in nature. As a result, we cannot say with certainty whether individual attitudes and predispositions are the consequence of certain policies or their drivers. Further research on the relationship between labor market policies and workers' employment flexibility should therefore be based on longitudinal data. Moreover, we need to investigate the actual consequences of individuals' stated willingness to be flexible with respect to their employment status and the policies they demand, as well as whether and how previous experiences with unemployment affect attitudinal employment flexibility. Despite these shortcomings, however, we believe that the results of this study, together with further research on the relationships between labor market policies and individuals' willingness to be flexible, will be important for organizations and policymakers seeking to further implement "flexicurity" strategies.

\section{References}

Abraham, K. G., \& Houseman, S. N. (1994). Does employment protection inhibit labor market flexibility? Lessons from Germany, France, and Beligum. In R. M. Blank (Ed.), Social Protection versus Economic Flexibility (pp. 69-93). Chicaco, IL: University of Chicago Press.

Acemoglu, D., \& Shimer, R. ( 2000). Productivity Gains from Unemployment Insurance. European Economic Review, 44(7), 1195-1224.

Addison, J. T., \& Grosso, J. L. (1996). Job security provisions and employment: Revised estimates. Industrial Relations: A Journal of Economy and Society, 35(4), 585-603.

Addison, J. T., \& Teixeira, P. (2003). The economics of employment protection. Journal of Labor Research, 24(1), 85-129.

Addison, J. T., Teixeira, P., \& Grosso, J. L. (2000). The effect of dismissals protection on employment: more on a vexed theme. Southern Economic Journal, 67(1), 105-122.

Akerlof, G.-. (1982). Labor Contracts as Partial Gift Exchange. Quarterly Journal of Economics, 97(4), 543-569. 
Anderson, C. J. ( 2009). The private consequences of public policies: Active labor market policies and social ties in Europe. European Political Science Review, 1(3), 341-373.

Anderson, C. J., \& Pontusson, J. (2007). Workers, worries and welfare states: Social protection and job insecurity in 15 OECD countries. European Journal of Political Research, 46(2), 211-235.

Bernhardt, J., \& Krause, A. (2014). Flexibility, performance and perceptions of job security: a comparison between East and West German employees in standard employment relationships. Work, Employment, and Society, 28(2), 285-304.

Bertola, G. (1999). Microeconomic perspectives on aggregate labor markets. In O. Ashenfelter \& D. Card (Eds.), Handbook of labor economics (Vol. 3, pp. 2985-3028). Amsterdam, NL: Elsevier.

Bertola, G., Blau, F. D., \& Kahn, L. M. (2007). Labor market institutions and demographic employment patterns. Journal of Population Economics, 20(4), 833-867.

Biggart, N. W., \& Castanias, R. P. (2001). Collateralized Social Relations: The Social in Economic Calculation. American Journal of Economics and Sociology, 60(2), 471500.

Blanchard, O., \& Katz, L. F. (1997). What We Know and Do Not Know About the Natural Rate of Unemployment. The Journal of Economic Perspectives, 11(1), 51-72.

Blanchard, O., \& Landier, A. (2002). The perverse effects of partial labour market reform: Fixed-term contracts in France. The Economic Journal, 112(480), F214-F244.

Blanchard, O., \& Wolfers, J. (2000). The Role of Shocks and Institutions in the Rise of European Unemployment: The Aggregate Evidence. The Economic Journal, 110(462), C1-C33.

Boeri, T., \& Garibaldi, P. (2007). Two tier reforms of employment protection: a honeymoon effect? Economic Journal, 117(521), 357-385.

Booth, A., Francesconi, M., \& Frank, J. (2002). Temporary jobs: stepping stones or dead ends? Economic Journal, 112(480), 189-213.

Bruch, S. K., Ferree, M. M., \& Soss, J. (2010). From Policy to Polity: Democracy, Paternalism, and the Incorporation of Disadvantaged Citizens American Sociological Review, 75(2), 205-226.

Cahuc, P., \& Postel-Vinay, F. (2002). Temporary jobs, employment protection and labor market performance. Labour Economics, 9(1), 63-91.

Campbell, A. L. (2003). How Policies Make Citizens: Senior Political Activism and the American Welfare State. Princeton, NJ: Princeton University Press.

Campbell, A. L. (2008). Policy Feedbacks and the Political Mobilization of Mass Publics. Unpublished MS. Department of Political Science, M.I.T.

Card, D., \& Levine, P. (2000). Extended Benefits and the Duration of UI Spells: Evidence from the New Jersey Extended Benefit Program. Journal of Public Economics, 78(107-138).

Chetty, R. (2008). Moral Hazard versus Liquidity and Optimal Unemployment Insurance. Journal of Political Economy, 116(2), 173-234.

Chung, H., \& van Oorschot, W. (2011). Institutions or market powers? Explaining employment insecurity of European individuals in (the beginning of) the financial crisis. Journal of European Social Policy, 21(4), 287-301.

Clark, A., \& Postel-Vinay, F. (2009). Job security and job protection. Oxford Economic Papers, 61(2), 207-239.

Decker, P. T. (1997). Work Incentives and Disincentive. In C. O'Leary \& S. A. Wandner (Eds.), Unemployment Insurance in the United States: Analysis of Policy Issues (pp. 286-320). Kalamazoo, MI: W.E. Upjohn Institute for Employment Research. 
Dixon, J. C., Fullerton, A. S., \& Robertson, D. L. (2013). Cross-national differences in workers' perceived job, labour market, and employment insecurity in Europe: Empirical tests and theoretical extensions. European Sociological Review, 29, 10531067.

Elster, J. (Ed.). (1986). Rational Choice. Washington Square, NY: New York University Press Esping-Andersen, G., \& Regini, M. (Eds.). (2000). Why deregulate labour markets? New York: Oxford University Press.

European Commission, E. (2007). Employment in Europe. In D. E. a. S. Affairs (Ed.). Brussels, Belgium.

Fleckenstein, T. (2008). Restructuring welfare for the unemployed: the Hartz legislation in Germany. Journal of European social policy, 18(2), 177.

Fleckenstein, T., Saunders, A. M., \& Seeleib-Kaiser, M. (2011). The Dual Transformation of Social Protection and Human Capital Comparing Britain and Germany. Comparative Political Studies, 44(12), 1622-1650.

Frank, R. H. (1993). The Strategic Role of the Emotions: Reconciling Over-And Undersocialized Accounts of Behavior. Rationality and Society, 5(2), 160-184. Fredriksson, P., \& Holmlund, B. (2006). Improving incentives in unemployment insurance: A review of recent research. Journal of Economic Surveys, 20(3), 357-386.

Gangl, M. (2003). Unemployment insurance and the stability of earnings: A comparison of work exits from unemployment in the United States and West Germany. Schmollers Jahrbuch - Journal of Applied Social Science Studies 123(1), 83-94.

Gangl, M. (2006). Scar Effects of Unemployment: An Assessment of Institutional Complementarities. American Sociological Review, 71(6), 986-1013.

Gebel, M., \& Giesecke, J. (2009). Labour market flexibility and inequality: the changing risk patterns of temporary employment in West Germany. Journal for Labour Market Research (Zeitschrift für Arbeitsmarktforschung), 42(3), 234-251.

Giesecke, J. (2009). Socio-economic risks of atypical employment relationships. Evidence from the German labour market. European Sociological Review, 25(6), 629-646.

Giesecke, J., \& Gross, M. (2003). Temporary employment: Chance or risk? European Sociological Review, 19(2), 161-177.

Givan, R. K., \& Hipp, L. (2012). Public Perceptions of Union Efficacy A Twenty-Four Country Study. Labor Studies Journal, 37(1), 7-32.

Hacker, J. S. (2002). The divided welfare state : the battle over public and private social benefits in the United States. New York: Cambridge University Press.

Hasenfeld, Y., Ghose, T., \& Larson, K. (2004). The Logic of Sanctioning Welfare Recipients: An Empirical Assessment. Social Service Review, 78(2), 304-319.

Jahoda, M. (1982). Employment and unemployment: a social-psychological analysis. Cambridge, New York: University Press.

Judge, T. A., Heller, D., \& Mount, M. K. (2002). Five-Factor Model of Personality and Job Satisfaction: A Meta-Analysis. Journal of Applied Psychology, 87(3), 530-541.

Kahn, L. M. (2007). The impact of employment protection mandates on demographic temporary employment patterns: international microeconomic evidence. Ecnomic Journal, 117(521), 333-356.

Kahn, L. M. (2010). Employment protection reforms, employment, and the incidence of temporary jobs in Europe: 1996-2001. Labour Economics, 17, 1-15.

Kalil, A., Seefeldt, K. S., \& Wang, H. Ä. (2002). Sanctions and Material Hardship under TANF. Social Service Review, 76(4), 642-662.

Kugler, A., Jimeno, J. F., \& Hernanz, V. (2005). Employment consequences of restrictive permanent contracts: evidence form Spanish labor market reforms. Working Paper. University of Huston. Huston, TX. 
Kugler, A., \& Pica, G. (2008). Effects of employment protection on worker and job flows: evidence from the 1990 Italian reform. Labour Economics, 15(1), 78-95.

Kumlin, S. (2004). The Personal and the Political: How Personal Welfare State Experiences Affect Political Trust and Ideology. New York: Palgrave Macmillan.

Kumlin, S., \& Rothstein, B. (2005). Making and Breaking Social Capital: The Impact of Welfare State Institutions. Comparative Political Studies, 38(4), 339-365.

Lalive, R. (2007). Unemployment benefits, unemployment duration, and post-unemployment jobs: A regression discontinuity approach. The American Economic Review, 97(2), 108-112.

Lazear, E. P. (1990). Job Security Provisions and Employment. The Quarterly Journal of Economics, 105(3), 699-726.

Mettler, S. B. (2002). Bringing the State Back In to Civic Engagement: Policy Feedback Effects of the GI Bill for World War II Veterans. American Political Science Review, 96(2), 351-365.

Mettler, S. B., \& Soss, J. ( 2004). The Consequences of Public Policy for Democratic Citizenship: Bridging Policy Studies and Mass Politics. Perspectives on Politics, 2(1), 55073.

Muffels, R. J. A. (Ed.). (2008). Flexibility and employment security in Europe: labour markets in transition. Cheltenham, UK: Edward Elgar.

Nickell, S. (1997). Unemployment and Labor Market Rigidities: Europe versus North America. The Journal of Economic Perspectives, 11(3), 55-74.

Nickell, S., \& Layard, R. (1999). Labor market institutions and economic performance. In O. Ashenfelter \& D. Card (Eds.), Handbook of labor economics (Vol. 3, pp. 3029-3084). Amsterdam, NL: Elsevier.

OECD (Organisation of Economic Cooperation and Development) (2004). Employment outlook. Paris, France.

Pescosolido, B. A. (1992). Beyond Rational Choice - the Social Dynamics of How People Seek Help. American Journal of Sociology, 97(4), 1096-1138.

Pierson, P. (1993). When Effect Becomes Cause: Policy Feedback and Political Change. World Politics, 45(4), 595-625.

Pissarides, C. A. (2000). Equilibrium unemployment theory. Cambridge, London: MIT press.

Rabe-Hesketh, S., \& Skrondal, A. (2012). Multilevel and longitudinal modeling using Stata (Vol. I \& II). College Station, TX: Stata Press.

Rueda, D. (2005). Insider-outsider politics in industrialized democracies: The challenge to social democratic parties. American Political Science Review, 99(01), 61-74.

Siebert, H. (1997). Labor Market Rigidities: At the Root of Unemployment in Europe. The Journal of Economic Perspectives, 11(3), 37-54.

Simon, H. A. (1957). Models of man: social and rational. Mathematical essays on rational human behavior in society setting. New York: Wiley.

Skocpol, T. (1992). Protecting Soldiers and Mothers: The political origins of social policy in the United States. Cambridge, Mass: Belknap Press of Harvard University Press.

Smith, V. L. (1991). Rational Choice - the Contrast between Economics and Psychology. Journal of Political Economy, 99(4), 877-897.

Soidre, T. (2004). Unemployment risks and demands on labour-market flexibility: an analysis of attitudinal patterns in Sweden. International Journal of Social Welfare, 13(2), 124133.

Soss, J. (1999). Lessons of Welfare: Policy Design, Political Learning, and Political Action. American Political Science Review, 93(2), 363-380. 
Soss, J., Fording, R. C., \& Schram, S. F. (2008). The Color of Devolution: Race, Federalism, and the Politics of Social Control. American Journal of Political Science, 52(3), 536553.

Tversky, A., \& Kahneman, D. (1981). The framing of decisions and the psychology of choice. Science, 211(4481), 453-458.

van Ours, J., C., \& Vodopivec, M. (2006). How shortening the potential duration of unemployment benefits affects the duration of unemployment: Evidence from a natural experiment. Journal of Labor Economics, 24(2), 351-350.

Western, B., \& Beckett, K. (1999). How Unregulated Is the U.S. Labor Market? The Penal System as a Labor Market Institution. American Journal of Sociology, 104(4), 10301060.

Wilthagen, T. (1998). Flexicurity: a new paradigm for labour market policy research. $W Z B$ Discussion Paper FS, Berlin( I 98-202).

Wilthagen, T., \& Tros, F. (2004). The concept of 'flexicurity': a new approach to regulating employment and labour markets. Transfer: European Review of Labour and Research, 10(2), 166-186.

Young, C. (2010). Unemployment Insurance and Job Search Effort:

Evidence from Random Audits Working Paper. Princeton University.

Zylan, Y., \& Soule, S. A. (2000). Ending welfare as we know it (again): Welfare state retrenchment, 1989-1995. Social Forces, 79(2), 623-652.

\section{Data}

More information about the ISSP data can be found at www.issp.org and more information about the OECD data at http://www.oecd-ilibrary.org/statistics. 
Figure 1. Strength of dismissal protection and generosity of unemployment benefits (2005).

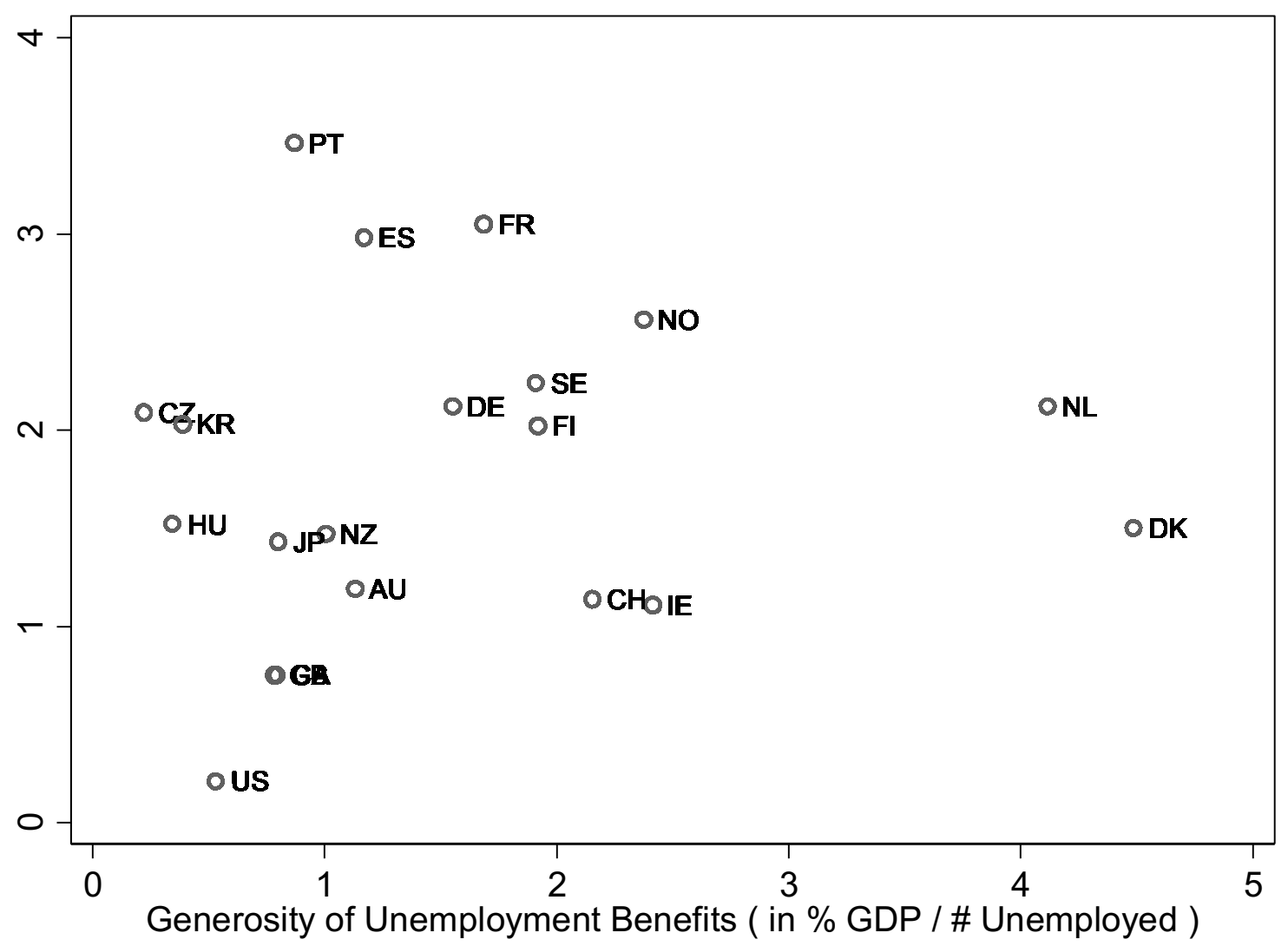

Note: The dismissal protection indicator has been developed by the OECD and refers to the protection of regular as well as temporary employment. The generosity of unemployment benefits is measured in \% GDP in proportion to the total number of unemployed.

Source: OECD 2005 [stats.oecd.org/index.aspx] 
Figure 2. Weighted means of attitudinal employment flexibility in study countries (2005).

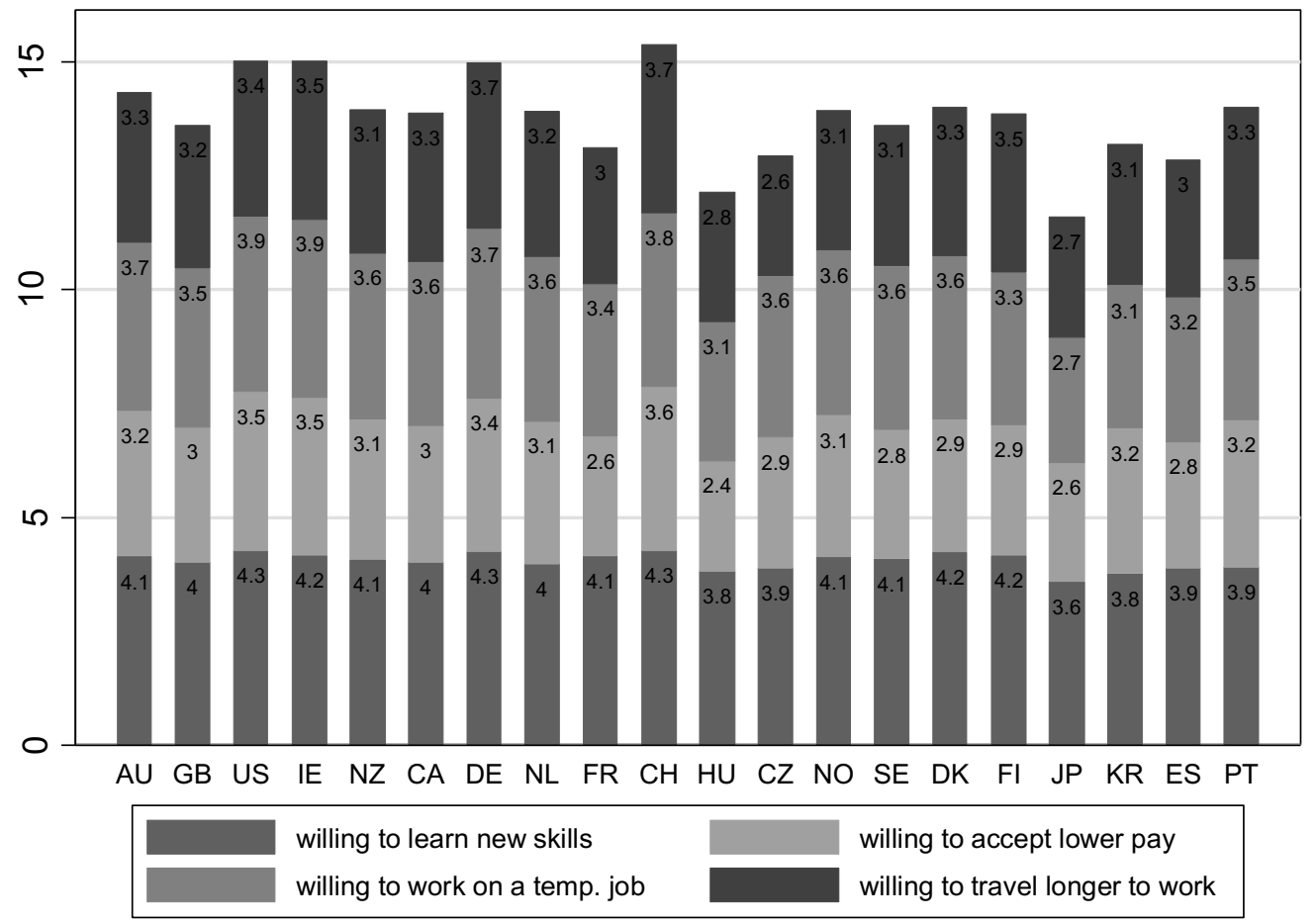

Note: This graph displays the weighted means of attitudinal employment flexibility as well as its components for the countries used in our study (Source: ISSP 2005). 
Figure 3. Relationship between unemployment benefits and attitudinal employment flexibility.

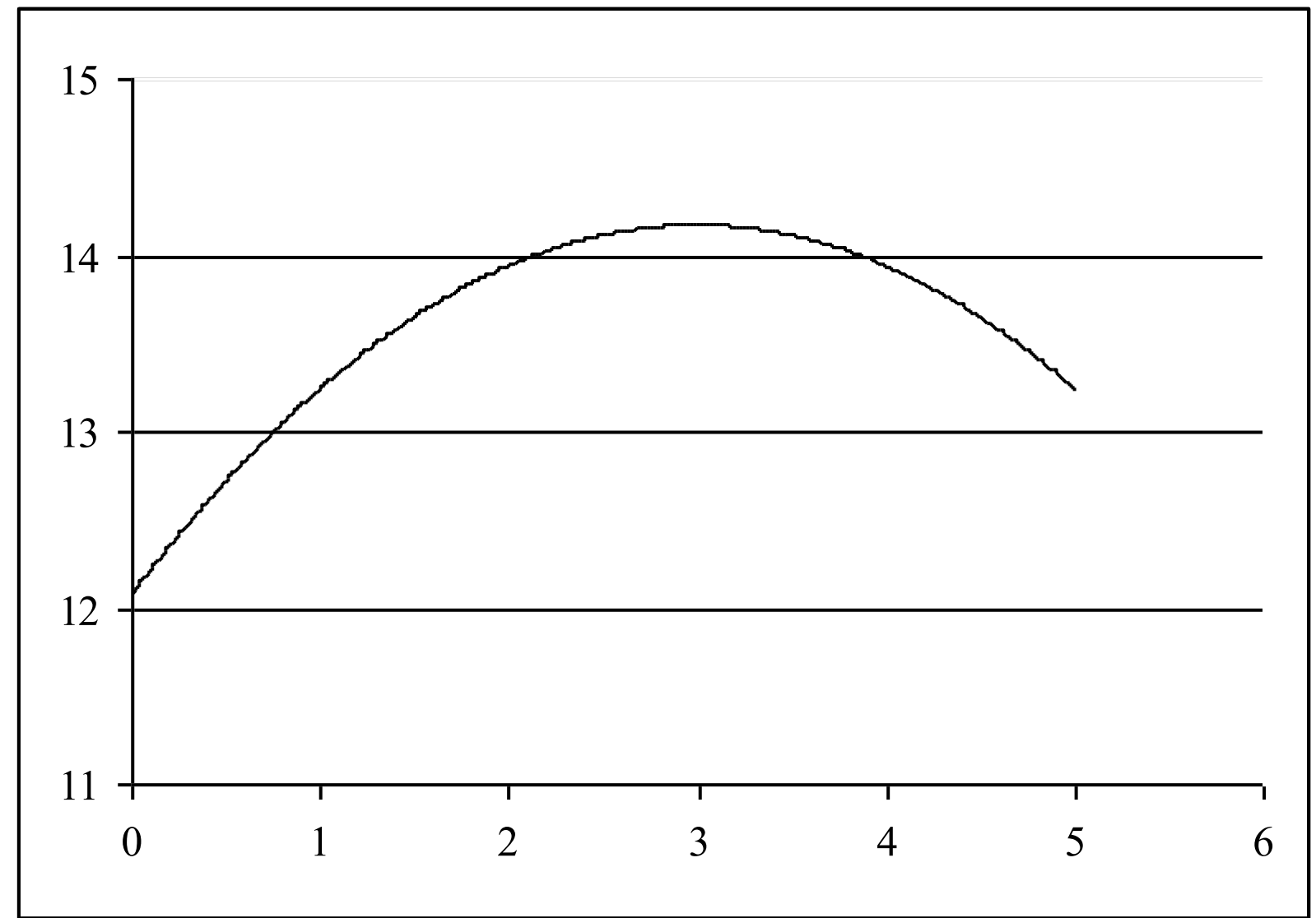

Note: This graph captures the association between attitudinal employment flexibility (y-axis) and unemployment benefits expressed in percentage GDP adjusted by the number of unemployed individuals (x-axis) net off all other variables used in our analyses. 
Figure 4. Relationship between dismissal protection and attitudinal employment flexibility.

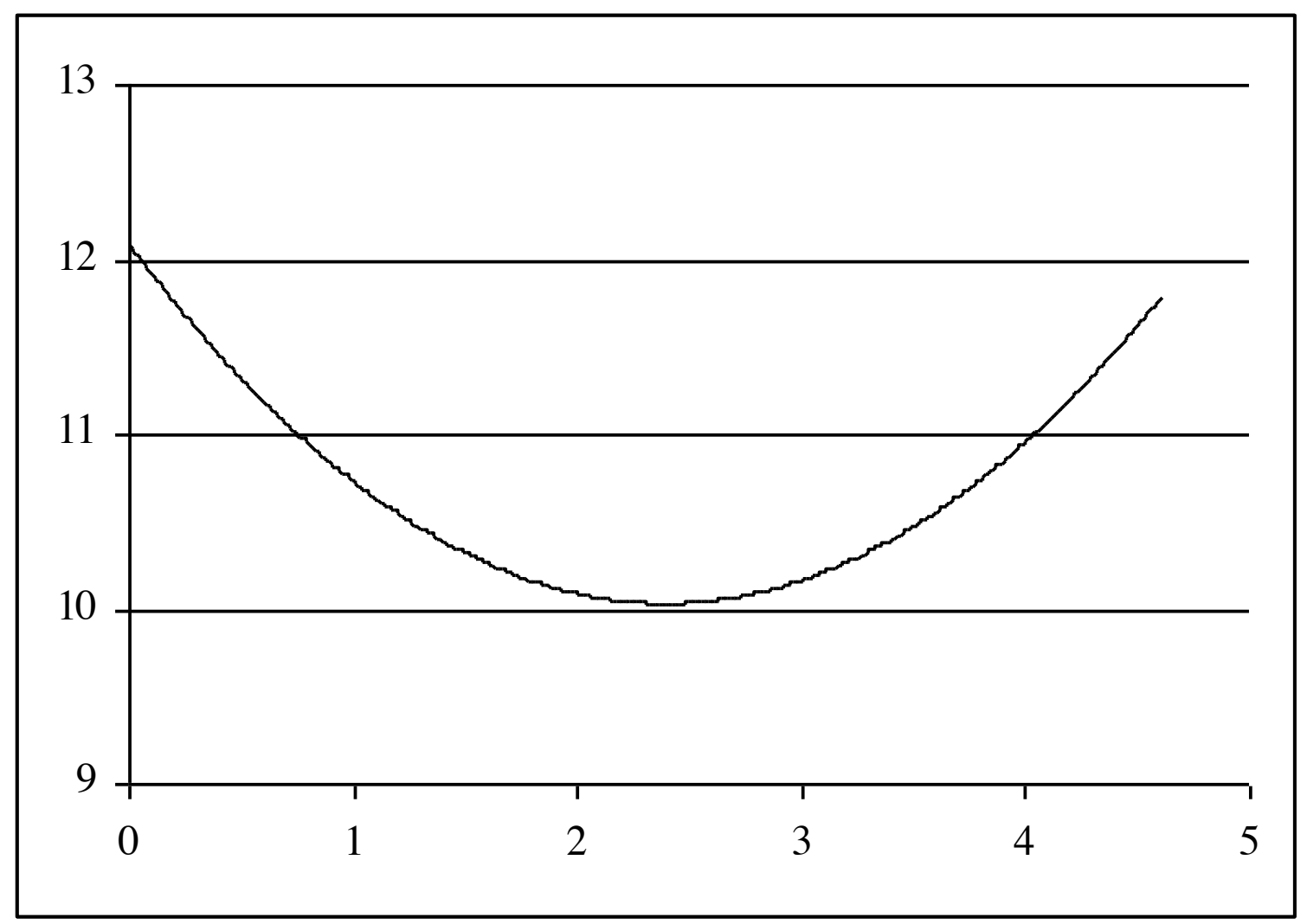

Note: This graph captures the association between attitudinal employment flexibility (y-axis) and the strength of dismissal protection (x-axis) net off all other variables used in our analyses. 
Table 1. Means, standard deviations, and correlations of study variables.

\begin{tabular}{|c|c|c|c|c|c|c|c|c|c|c|c|c|c|c|c|c|c|c|c|c|}
\hline & & Mean & S.D. & 1 & 2 & 3 & 4 & 5 & 6 & 7 & 8 & 9 & 10 & 11 & 12 & 13 & 14 & 15 & 16 & 17 \\
\hline 1 & Attitudinal Employment Flexibility & 13.9 & 3.4 & 1 & & & & & & & & & & & & & & & & \\
\hline 2 & Gender & 0.5 & 0.5 & -0.02 & 1 & & & & & & & & & & & & & & & \\
\hline 3 & Relationship Status & 0.4 & 0.5 & 0.03 & 0.06 & 1 & & & & & & & & & & & & & & \\
\hline 4 & Flexibility of Partner & 0.4 & 0.5 & -0.04 & 0.2 & -0.62 & 1 & & & & & & & & & & & & & \\
\hline 5 & Presence of Child(ren) in $\mathrm{HH}$ & 0.4 & 0.5 & 0.03 & 0.02 & -0.27 & 0.17 & 1 & & & & & & & & & & & & \\
\hline 6 & Age & 41.9 & 11.6 & -0.15 & -0.05 & -0.28 & 0.1 & -0.16 & 1 & & & & & & & & & & & \\
\hline 7 & Education & -1.2 & 10.5 & 0.07 & 0.02 & 0.09 & -0.02 & -0.03 & -0.15 & 1 & & & & & & & & & & \\
\hline 8 & Blue Collar Worker & 0.3 & 0.4 & -0.07 & -0.28 & -0.03 & -0.07 & -0.01 & 0.04 & -0.14 & 1 & & & & & & & & & \\
\hline 9 & Union Member & 0.3 & 0.5 & -0.01 & 0.02 & -0.07 & 0.08 & 0 & 0.11 & -0.04 & -0.03 & 1 & & & & & & & & \\
\hline 10 & Public Service Worker & 0.3 & 0.5 & 0 & 0.17 & -0.02 & 0.07 & 0.01 & 0.06 & 0.05 & -0.21 & 0.32 & 1 & & & & & & & \\
\hline 11 & Job Satisfaction & 5.3 & 1.1 & 0.09 & 0 & -0.05 & 0.02 & 0.01 & 0.07 & 0.01 & -0.06 & 0.01 & 0.03 & 1 & & & & & & \\
\hline 12 & Working Hours & 0.8 & 0.4 & 0.05 & -0.28 & -0.03 & -0.04 & -0.06 & -0.03 & -0.07 & 0.09 & 0.08 & -0.04 & -0.01 & 1 & & & & & \\
\hline 13 & Supervisory Position & 0.3 & 0.5 & 0.11 & -0.17 & -0.07 & 0 & 0.03 & 0.08 & 0.04 & -0.15 & -0.02 & -0.02 & 0.1 & 0.13 & 1 & & & & \\
\hline 14 & Ø Unemployment 2000-2005 & 6 & 1.9 & -0.08 & 0.01 & -0.07 & 0.06 & 0.02 & -0.05 & -0.06 & 0.04 & -0.04 & 0.02 & -0.04 & 0.07 & -0.04 & 1 & & & \\
\hline 15 & $\Delta$ in Uneemployment $2004-05$ & 0.5 & 0.5 & 0.01 & 0 & -0.05 & 0.04 & -0.02 & 0.03 & -0.02 & 0.01 & 0.04 & -0.02 & 0.04 & 0.02 & 0.01 & 0.16 & 1 & & \\
\hline 16 & Dismissal Protection & 1.8 & 0.9 & -0.09 & 0.02 & -0.01 & 0.03 & 0.05 & -0.06 & -0.04 & 0.04 & 0.01 & 0.02 & -0.07 & 0.07 & -0.09 & 0.38 & -0.51 & 1 & \\
\hline 17 & Unempl. Benefits & 1.5 & 1.1 & 0.07 & 0 & 0.09 & -0.02 & 0.02 & 0.04 & -0.09 & -0.1 & 0.32 & 0.13 & 0.09 & -0.04 & 0.03 & -0.23 & -0.05 & 0.08 & 1 \\
\hline
\end{tabular}

$\mathrm{N}(1)=13,358$ and $\mathrm{N}(2)=20$ 
Table 2. Random Intercept models for attitudinal employment flexibility.

\begin{tabular}{|c|c|c|c|c|c|c|c|c|}
\hline & \multicolumn{2}{|c|}{ Model 1} & \multicolumn{2}{|c|}{ Model 2} & \multicolumn{2}{|c|}{ Model 3} & \multicolumn{2}{|c|}{ Model 4} \\
\hline & Coeff. & SE & Coeff. & SE & Coeff. & $\mathrm{SE}$ & Coeff. & SE \\
\hline Intercept & $13.760 * * *$ & $(0.20)$ & $12.004 * * *$ & $(0.44)$ & $12.273 * * *$ & $(0.76)$ & $12.644 * * *$ & $(0.83)$ \\
\hline \multicolumn{9}{|l|}{ Individual Level } \\
\hline Gender & & & 0.062 & $(0.08)$ & 0.065 & $(0.08)$ & 0.064 & $(0.08)$ \\
\hline Children & & & 0.064 & $(0.09)$ & 0.063 & $(0.09)$ & 0.063 & $(0.09)$ \\
\hline Gender*Children & & & $-0.356^{* *}$ & $(0.11)$ & $-0.355^{* *}$ & $(0.11)$ & $-0.356^{* *}$ & $(0.11)$ \\
\hline Relationship status & & & $-0.196^{*}$ & $(0.09)$ & $-0.201^{*}$ & $(0.09)$ & $-0.200^{*}$ & $(0.09)$ \\
\hline Partner Flexibility & & & $-0.212 * *$ & $(0.08)$ & $-0.214 * *$ & $(0.08)$ & $-0.213 * *$ & $(0.08)$ \\
\hline Age in years & & & $0.089 * * *$ & $(0.02)$ & $0.089 * * *$ & $(0.02)$ & $0.089 * * *$ & $(0.02)$ \\
\hline Age Square & & & $-0.002 * * *$ & $(0.00)$ & $-0.002 * * *$ & $(0.00)$ & $-0.002 * * *$ & $(0.00)$ \\
\hline Education in years (centered) & & & $0.013 * * *$ & $(0.00)$ & $0.013 * * *$ & $(0.00)$ & $0.013 * * *$ & $(0.00)$ \\
\hline Blue Collar Worker & & & $-0.404 * * *$ & $(0.07)$ & $-0.401 * * *$ & $(0.07)$ & $-0.400^{* * *}$ & $(0.07)$ \\
\hline Union Member & & & -0.063 & $(0.07)$ & -0.070 & $(0.07)$ & -0.071 & $(0.07)$ \\
\hline Public Service Worker & & & -0.061 & $(0.07)$ & -0.061 & $(0.07)$ & -0.061 & $(0.07)$ \\
\hline Job Satisfaction & & & $0.180 * * *$ & $(0.03)$ & $0.179^{* * *}$ & $(0.03)$ & $0.179 * * *$ & $(0.03)$ \\
\hline Working Hours & & & $0.413 * * *$ & $(0.08)$ & $0.417 * * *$ & $(0.08)$ & $0.418^{* * *}$ & $(0.08)$ \\
\hline Supervisory Position & & & $0.439 * * *$ & $(0.06)$ & $0.438 * * *$ & $(0.06)$ & $0.437 * * *$ & $(0.06)$ \\
\hline \multicolumn{9}{|l|}{ Country Level } \\
\hline 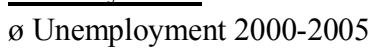 & & & & & 0.016 & $(0.10)$ & -0.031 & $(0.09)$ \\
\hline$\Delta$ in Unemployment $2004-05$ & & & & & -0.279 & $(0.39)$ & -0.132 & $(0.33)$ \\
\hline Dismissal Protection & & & & & -0.406 & $(0.26)$ & $-1.644^{*}$ & $(0.69)$ \\
\hline Unempl. Benefits & & & & & $0.334 *$ & $(0.15)$ & $1.349 * *$ & $(0.43)$ \\
\hline Dismissal Protection Squared & & & & & & & 0.329 & $(0.17)$ \\
\hline Unempl. Benefits Squared & & & & & & & $-0.215^{*}$ & $(0.09)$ \\
\hline \multicolumn{9}{|l|}{ Random Components } \\
\hline$\sqrt{\psi}($ Country Level) & $0.891 * * *$ & $(0.14)$ & $0.842 * * *$ & $(0.14)$ & $0.712 * * *$ & $(0.12)$ & $0.581 * * *$ & $(0.10)$ \\
\hline$\sqrt{\mathrm{q}}$ (Individual Level) & $3.261 * * *$ & $(0.02)$ & $3.178 * * *$ & $(0.02)$ & $3.178 * * *$ & $(0.02)$ & $3.178 * * *$ & $(0.02)$ \\
\hline \multicolumn{9}{|l|}{ Model Fit } \\
\hline$\overline{\text { LR Chi Square }}$ & 0.00 & & 675.81 & & 682.34 & & 690.04 & \\
\hline rho & 0.07 & & 0.07 & & 0.05 & & 0.03 & \\
\hline R-Square (indivdiual) & & & .028 & & .028 & & .028 & \\
\hline R-square (country) & & & .032 & & .135 & & .291 & \\
\hline
\end{tabular}

$* \mathrm{p}<0.05, * * \mathrm{p}<0.01, * * * \mathrm{p}<0.001$

Note: The group variable is country code. $\mathrm{N}($ Level 1$)=13,358 ; \mathrm{N}($ Level 2) $=20$ 
To compare the model fit, $\chi^{2}$-tests of deviance (=-2LogDeviance) were conducted. Smaller deviances indicate better model fit. The $\chi^{2}-$ value is calculated based on the difference between the deviances of two models; the degrees of freedom are the differences in the number of parameters between the models. These $\chi^{2}-$ tests of deviance indicate that Model 4 fits the data considerably better than Model $3(\mathrm{p}<0.05)$. 